\title{
APLIKASI SISTEM INFORMASI GEOGRAFIS UNTUK PEMETAAN TAMBAK GARAM DI KABUPATEN SIDOARJO
}

\author{
Dwi Budi Wiyanto (1), Dyah Ayu Sulistiorini (2) \\ ${ }^{1}$ Program Studi Ilmu Kelautan Universitas Udayana \\ ${ }^{2}$ Program Studi IImu Kelautan Universitas Trunojoyo Madura \\ 1'wiyanto_marine@yahoo.com
}

\begin{abstract}
ABSTRAK
Sistem Informasi Geografis dapat digunakan untuk memetakan lahan tambak garam yang juga dapat diisi oleh banyak informasi dari pemilik, produksi, serta luasan dari tiap petak tambak garam sehingga nantinya dapat menjadi suatu informasi yang lengkap untuk keperluan database pemerintah maupun instansi terkait. Penelitian ini bertujuan untuk memetakan potensi lahan tambak garam di wilayah Kabupaten Sidoarjo serta mengetahui cakupan luas lahan produksi tambak garam di Kabupaten Sidoarjo. Hasilnya menunjukkan bahwa luas lahan tambak garam di Kabupaten Sidoarjo adalah 351,59 Ha dengan 162,5 Ha diantaranya adalah lahan produktif. Analisa yang dilakukan terhadap trend produksi garam di Kabupaten Sidoarjo menunjukkan hasil yang berfluktuatif pada periode tahun 2000 hingga 2016. Fluktuasi produksi ini diakibatkan oleh perubahan kondisi cuaca. Rendahnya produksi garam pada tahun 2005 dan 2010 diduga sebagai akibat dari pengaruh adanya musim hujan dengan periode yang panjang.
\end{abstract}

Kata Kunci : Sistem Informasi Geografis, Tambak Garam, Sidoarjo

\section{ABSTRACT}

Geographic Information System is useful to map salt ponds which can be combined with many other information such as name of owners, ponds area. Those information are important and functioned as database for governments and related institutions. Objective of this research is to map and measure salt pond area in Sidoarjo district of East Java. The results show that total salt pond area of Sidoarjo is around 351,59 Ha. However only 162,5 Ha of the total area can be classified as productive land. Further analysis showed that between 2000 until 2016, salt production of Sidoarjo was fluctuated due to weather condition. In 2005 and 2010, salt production in Sidoarjo reached its lowest. This condition occurred because long period of rainy season in Indonesia during 2005 and 2010.

Keywords : Geographic Information System, Salt Ponds, Sidoarjo

\section{PENDAHULUAN}

Garam merupakan salah satu bahan pokok yang dibutuhkan dalam kehidupan sehari - hari, salah satu diantaranya dalam hal memasak. Proses terbentuknya garam sendiri sangatlah sederhana dengan memanfaatkan penguapan yang berasal dari sinar matahari sehingga menyisakan mineral - mineral yang mengendap. Untuk lahan tambak garam sendiri dibuat dalam bentuk petakan kecil yang terdapat di dalam satu petakan yang besar (Purbani, 2011). Pembuatan garam secara tradisional, dapat dilakukan dengan cara meratakan petak petak tambak dengan menggunakan alat bantu yang telah terbuat dari bahan silinder baja yang dapat ditarik menggunakan tenaga manusia. Kemudian lahan tambak 
garam itu diisi air laut dan dengan bantuan sinar matahari, air laut dapat mengkristal dan berubah menjadi butiran garam. Pemanenan garam dapat dilakukan setelah 10 hari dan itu berlangsung pada bulan April hingga awal Desember (Adiraga dan Setiawan, 2014). Untuk saat ini tingkat produksi lahan penggaraman di Indonesia rata-rata baru mencapai sebesar 60-70 ton/hektar/tahun, cukup rendah apabila dibandingkan dengan Australia atau India. Pada tahun 2009, produksi garam nasional mencapai 1.265.600 ton, masih jauh lebih rendah dari kebutuhan garam nasional yang mencapai sebesar 2.865.600 ton per tahun ini di tandai dengan selalu meningkatnya permintaan konsumsi kebutuhan garam yang dibarengi dengan pertambahan penduduk. Selama ini kebutuhan garam dapat dipenuhi melalui impor dan sebagian dari dalam negeri (Aprilia dan Ali, 2011).

Garam merupakan senyawa kimia yang sifatnya sederhana dan tersusun atas banyak atom positif maupun negative, dengan pembagian rumus kimia $\mathrm{NaCl}$ untuk setiap klor didapat lebih dari 60 persen sedangkan 40 persen untuk Na. Garam memiliki bentuk menyerupai Kristal yang memiliki nilai toksisitas rendah sehingga tidak dapat terbakar (Purbani, 2006). Menurut Wirjodirjo (2004) mengatakan bahwa untuk memodelkan suatu produksi garam dengan menggunakan pendekatan dinamis yang berdasarkan factor pengaruh terhadap usaha garam yaitu : (1) lahan, (2) curah hujan, serta (3) net evaporasi sangat berpengaruh terhadap produksi garam. Sedangkan menurut Rachman (2011) mengatakan bahwa ada beberapa factor yang dapat mempengaruhi tingkat produksi garam adalah : (1) lahan tambak garam termasuk salah satu pengaruh dari factor produksi garam rakyat yang secara garis besar dapat dilihat dari luasnya lahan tambak garam. (2) tenaga kerja yang terdapat di lahan tambak garam dalm proses produksi garam. (3) modal adalah hal yang terpenting dalam hal persiapan pengelolaan lahan hingga tahap produksi. (4) teknologi, dalam hal meningkatkan mutu dari garam yang telah diproduksi.
Menurut produsennya garam biasanya dibedakan atas garam rakyat dan garam pemerintah. Garam rakyat adalah garam yang diproduksi oleh petani garam. Garam rakyat biasanya diproduksi oleh penduduk tepi pantai atau penduduk di daerah sumber air asin. Sedangkan garam Pemerintah adalah garam yang diproduksi oleh pabrikpabrik garam. Berdasarkan bentuknya garam dibedakan atas garam yang berbentuk kristal dan garam briket yang dicetak. Komposisi beberapa zat utama (keadaan normal) dalam garam dapur menurut (Purbani,2006);

- Natrium Klorida ( $\mathrm{NaCl}) 77,76 \%$

- Magnesium Klorida $\left(\mathrm{MgCl}_{2}\right) 10,88 \%$

- Kalsium Sulfat $\left(\mathrm{CaSO}_{4}\right)$ 3,60 \%

- Magnesium Sulfat $\left(\mathrm{MgSO}_{4}\right) 4,47 \%$

- Kalium Sulfat $\left(\mathrm{K}_{2} \mathrm{SO}_{4}\right) 2,46 \%$

- Magnesium Bromida $\left(\mathrm{MgBr}_{2}\right)$ 0,22\%

- Kalsium Karbonat $\left(\mathrm{CaCO}_{3}\right)$ 0,34 \%

- Senyawa-senyawa lain 0,001\%

Pemetaan merupakan suatu proses yang berguna dan sangat penting dalam pengolahan citra satelit yang kemudian dapat di olah lebih lanjut dengan beberapa metode yang hasil akhirnya atau outputnya dalam bentuk peta. Peta disini berfungsi sebagai pemberi informasi mengenai kondisi pemukiman, tanah, lahan kosong, tambak, dan lain lain. Menurut Darmawan (2009) mengatakan bahwa peta juga dapat dimanfaatkan sebagai landasan pengaturan manajemen pengelolaan sumberdaya pesisir, menyediakan data dan informasi yang berkaitan mengenai penggunaan lahan di wilayah pesisir dan laut, serta membantu dalam hal system data base yang berguna untuk pengelolaan kawasan pesisir dan laut bagi keperluan pemerintah. Pemetaan juga dapat digunakan untuk memetakan lahan tambak garam yang juga dapat diisi oleh banyak informasi dari pemilik, produksi, serta luasan dari tiap petak tambak garam sehingga nantinya dapat menjadi suatu informasi yang lengkap untuk keperluan database pemerintah maupun instansi terkait (Tambunan et.al, 2012). Kegunaan lainnya dari memetakan lahan tambak garam ini, adalah dapat 
mengetahui petak tambak yang masih beroperasi dan yang tidak.

Untuk mengetahui titik lokasi petak tambak yang masih berproduksi dan yang tidak perlu dilakukan survey lapang serta wawancara. Tidak hanya itu untuk mengetahui luasan tiap petak perlu dilakukan digitasi dengan menggunakan citra resolusi tinggi yang terdapat pada Google Earth Pro.

Pertumbuhan serta perkembangan pemanfaatan lahan tambak garam di Kabupaten Sidoarjo menghadapi beberapa permasalahan dasar, yaitu:

1. Kurangnya informasi lengkap mengenai peta lahan tambak garam yang disertai informasi pemilik serta produksinya.

2. Belum adanya mengenai informasi luas lahan tambak tiap pemilik yang ada di tiap desa

3. Belum adanya pemetaan mengenai lahan yang berproduksi ataupun tidak di tiap lokasi atau desa

Oleh karena itu, tujuan penelitian ini adalah untuk memetakan potensi lahan tambak garam di wilayah Kabupaten Sidoarjo serta mengetahui cakupan luas lahan produksi tambak garam di Kabupaten Sidoarjo.

\section{METODE PENELITIAN}

\section{a. Alat dan Bahan}

Peralatan yang digunakan pada penelitian in merupakan alat yang digunakan untuk survey lapangan dan pengolahan data spasial. Peralatan tersebut antara lain adalah (1) Global Positioning System (GPS); (2) Alat transportasi; (3) Kamera dan (4) Perangkat computer. Sementara itu, data-data yang digunakan sebagai bahan dalam penelitian ini antara lain adalah (1) Citra satelit resolusi tinggi yang diperoleh dari Google Earth tahun 2016; (2) Data produksi garam dari Dinas Perikanan dan Kelautan Kabupaten Sidoarjo.

\section{b. Waktu dan Tempat Penelitian}

Penelitian ini dilaksanakan pada bulan Juni sampai dengan Agustus tahun 2017. Lokasi pelaksanaan penelitian ini adalah di wilayah pesisir Kabupaten Sidoarjo yang memiliki tambak garam, tepatnya di Kecamatan Sedati. Berdasarkan data dari Dinas Perikanan Kabupaten Sidoarjo lokasi tambak garam di Kecamatan ini tersebar di 3 desa yaitu Desa Banjar Kemuning, Tambak Cemandi dan Kalanganyar.

\section{c. Teknik Pengumpulan Data}

Data yang dikumpulkan dan dianalisa pada penelitian ini terdiri dari data spasial dan non-spasial. Untuk mengetahui titik lokasi petak tambak yang masih berproduksi dilakukan survey lapang serta wawancara. Sedangkan untuk mengetahui luasan tiap petak dilakukan digitasi dengan menggunakan citra resolusi tinggi yang diperoleh dari Google Earth.

Proses awal sebelum dilakukan digitasi tambak garam adalah dengan melakukan koreksi geometrik. Koreksi geometrik yang paling mendasar adalah pemetaan kembali posisi piksel sedemikian rupa sehingga dihasilkan obyek yang sesuai dengan kondisi sebenarnya di lapangan atau pada peta topografi. Pada koreksi geometrik terjadi pengalihan posisi (relokasi) seluruh piksel pada citra sehingga membentuk konfigurasi piksel baru yang dipersiapkan sebagai citra. Koreksi geometrik ini dilakukan dengan menggunakan rujukan titik-titik tertentu pada peta (peta topografi) yang mempunyai posisi kenampakan yang sama dengan titik-titk yang ada pada citra. Pasangan titik tersebut kemudian digunakan untuk membangun fungsi matematis yang menyebabkan hubungan posisi sembarang titik pada citra dengan titik yang sama pada peta. Hasilnya adalah citra digital memiliki koordinat baru dan konfigurasi piksel yang baru. Perubahan posisi piksel ini secara otomatis menyebabkan perubahan nilai spektral yang baru danmenyebabkan citra digital memiliki kesalahan radiometrik kembali, sehingga perlu penataan ulang piksel-piksel yang berubah tersebut. Metode yang diterapkan untuk mengembalikan posisi piksel-piksel citra digital adalah interpolasi nilai piksel citra atau disebut resampling. 


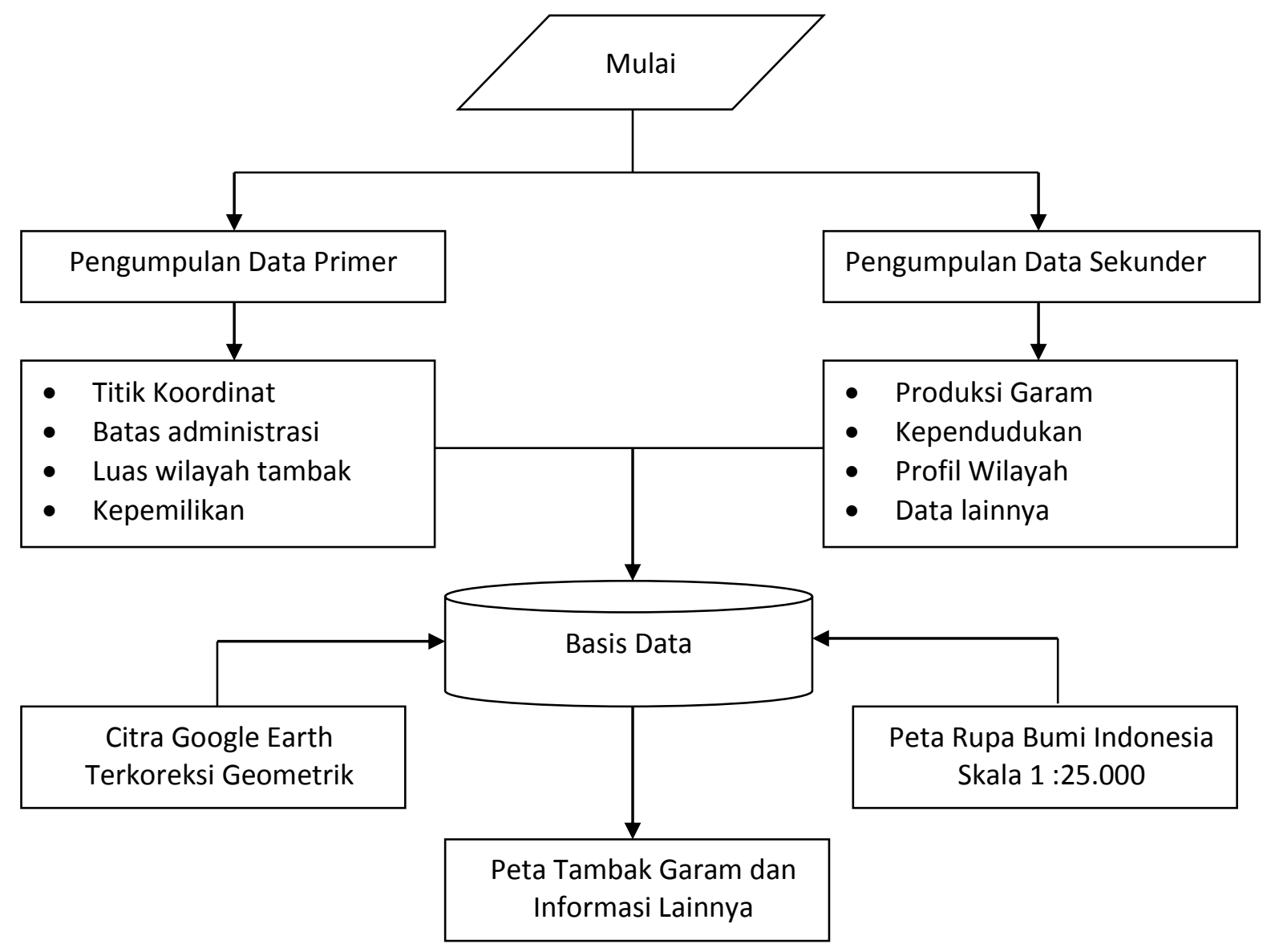

Gambar 1. Alur Pemetaan Tambak Garam di Kabupaten Sidoarjo

HASIL DAN PEMBAHASAN

- Gambaran Umum Kecamatan Sedati Kecamatan Sedati terletak di timur-utara Kabupaten Sidoarjo dan berjarak sekitar 14 kilometer dari kota Sidoarjo. Batas-batas Kecamatan Sedati adalah :

- sebelah barat berbatasan dengan Kecamatan Gedangan dan Buduran

- sebelah selatan berbatasan dengan Kecamatan Buduran

- sebelah utara berbatasan dengan Kecamatan Waru

- sebelah timur berbatasan dengan Selat Madura.

Kecamatan Sedati memiliki jumlah penduduk sebesar 92.643 jiwa dengan komposisi $57.5 \%$ penduduk laki-laki dan $42.5 \%$ penduduk perempuan. Luas wilayah
Kecamatan Sedati adalah $79.35 \mathrm{~km}^{2}$ yang terdiri dari 16 desa dan 35 dusun.

Potensi perikanan di Kecamatan Sedati terlihat dari luas tambak sebesar 4.100,5 hektar atau 26,39\% dari luas tambak Kabupaten Sidoarjo dan menjadi salah satu penyumbang produksi perikanan budidaya terbesar Sementara itu Kecamatan Sedati juga memiliki potensi perikanan tangkap dengan adanya depo dan pasar ikan yang menjadi pusat distribusi hasil perikanan tangkap. 


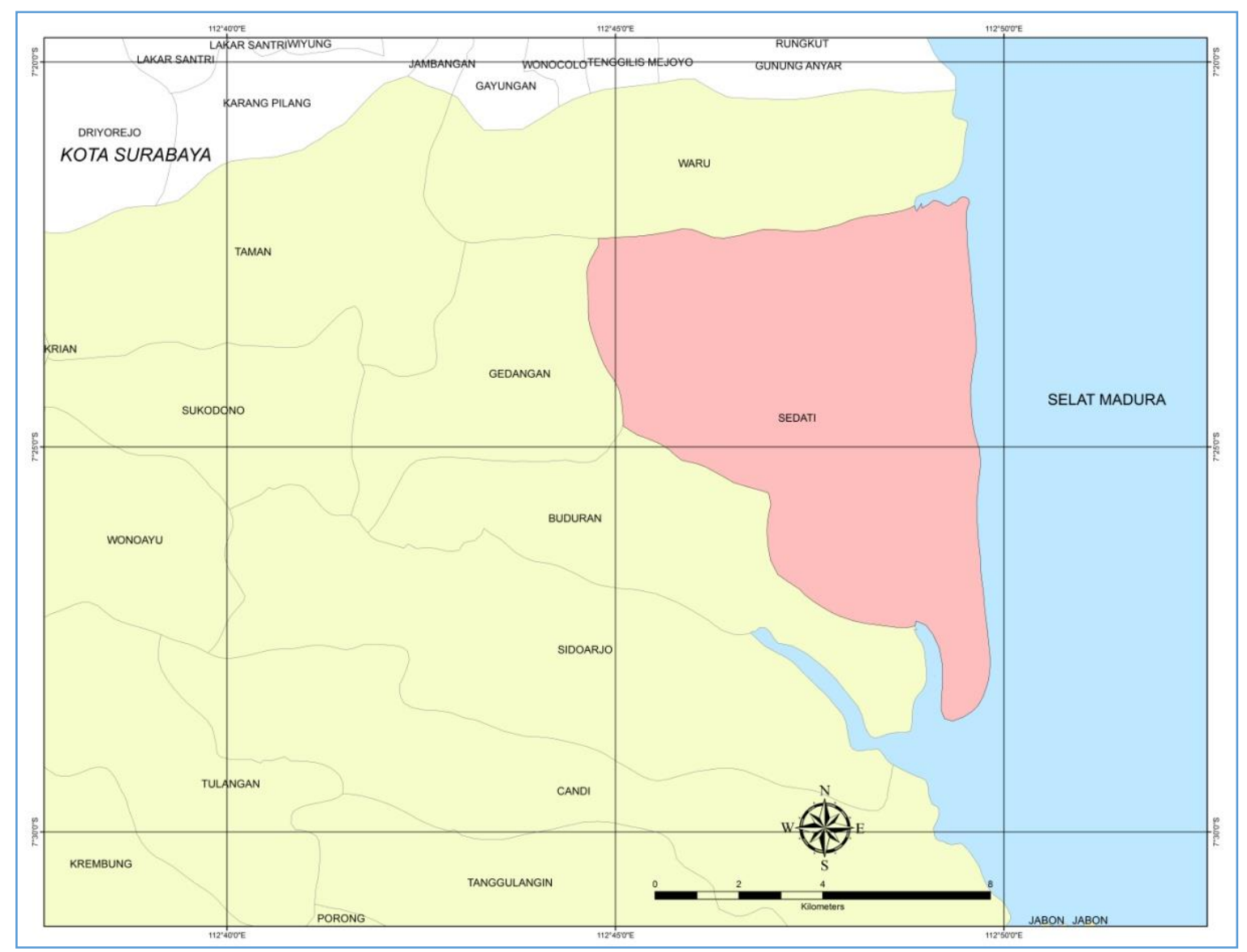

Gambar 2. Peta Kecamatan Sedati Kabupaten Sidoarjo

\section{Hasil Pemetaan Tambak Garam}

Peta tambak garam di Kecamatan Sedati Kabupaten Sidoarjo dibuat dengan menggunakan citra satelit resolusi tinggi yang diunduh melalui aplikasi Google Earth. Setelah dilakukan koreksi geometrik, maka langkah berikutnya adalah mendelineasi batas-batas lahan sesuai dengan kepemilikannya. Informasi terkait hal tersebut diperoleh dari masyarakat sekitar dan tenaga penyuluh lapangan dari Dinas Perikanan dan Kelautan Kabupaten Sidoarjo.

Delineasi bidang tanah merupakan salah satu dari komponen dalam pembangunan kadaster lengkap. Delineasi bidang tanah dilakukan dengan cara mengidentifikasi bidang- bidang tanah dengan menggunakan peta foto dan menarik garis ukur untuk batas bidang tanah yang jelas dan memenuhi syarat. Ada dua jenis kategori batas yang dapat dijadikan sebagai acuan dalam metode delineasi, antara lain adalah fixed boundaries dan general boundaries. Fixed boundaris adalah garis yang telah ditetapkan oleh yang berwenang melalui survei formal dan dinyatakan secara matematis oleh hubungan dan jarak, atau dengan koordinat. Sedangkan general boundaries adalah garis yang terlihat ada dalam kenyataan tetapi belum ditetapkan oleh pihak yang berwenang, biasanya batas tersebut berupa kenampakan fisik, baik alami atau buatan manusia seperti pagar, parit, atau jalan (Darmawan, 2012). Untuk pemetaan tambak garam pada penelitian ini, pendekatan yang digunakan adalah general boundaries dengan memperhatikan batas pematang setiap petak tambak. Hasilnya adalah sebagai berikut. 


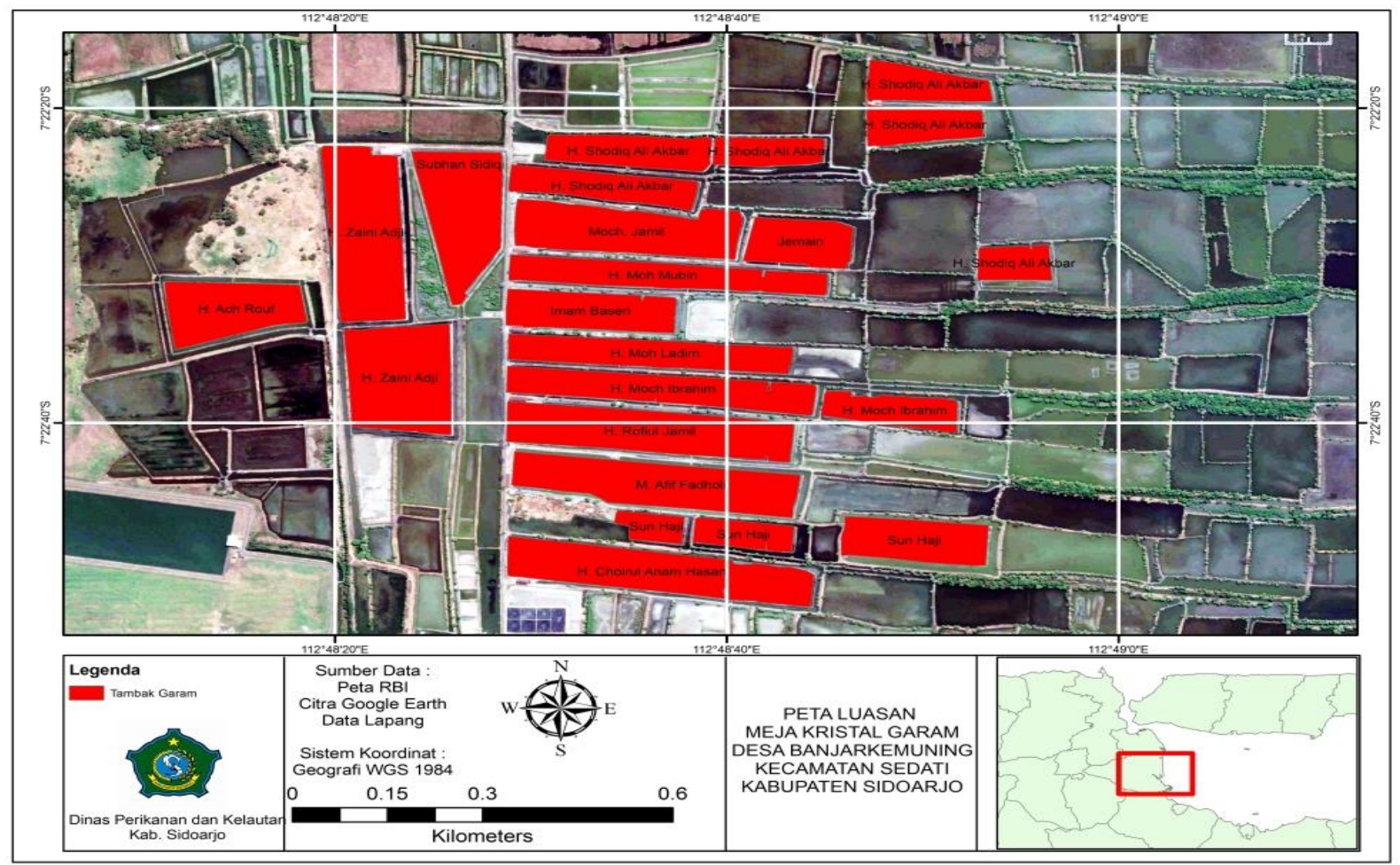

Gambar 3. Peta Tambak Garam Desa Banjar Kemuning

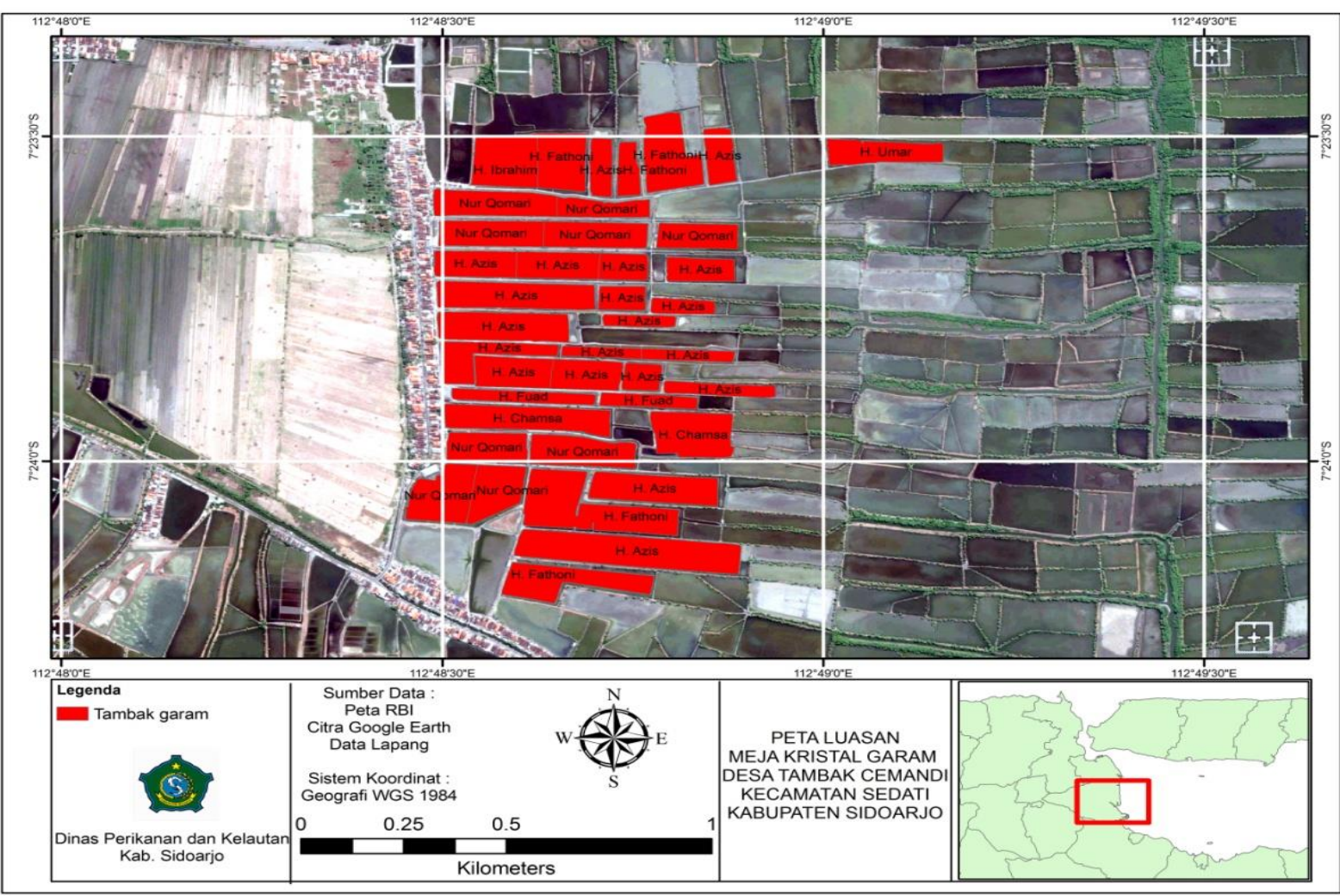

Gambar 4. Peta Tambak Garam Desa Tambak Cemandi 


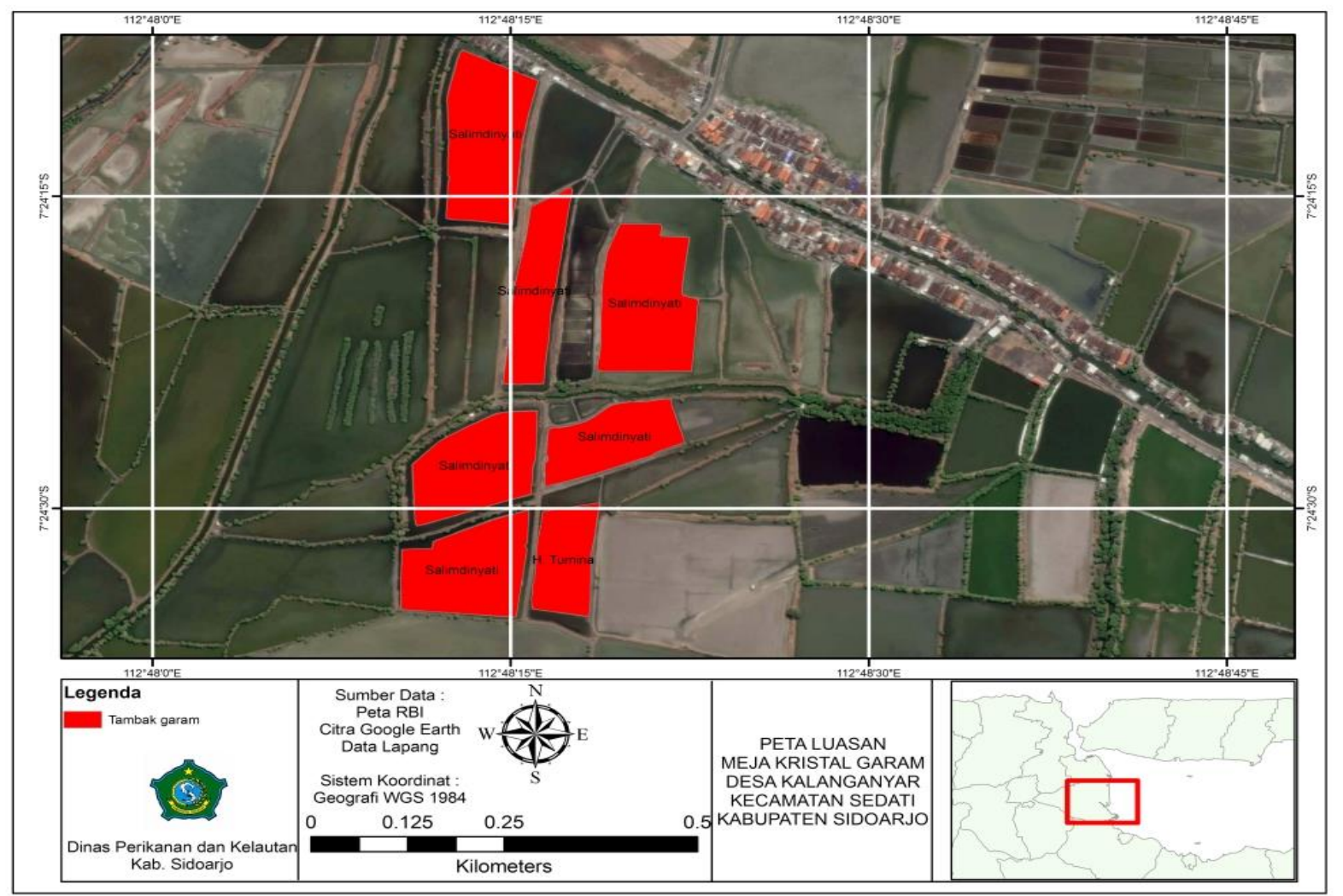

Gambar 3. Peta Tambak Garam di Desa Kalanganyar

Tabel 1. Luas Tambak Garam Hasil Pemetaan

\begin{tabular}{|c|c|c|c|c|}
\hline No & Nama Desa & $\begin{array}{c}\text { Luas Lahan } \\
\text { Tambak (Ha) }\end{array}$ & $\begin{array}{c}\text { Luas Area } \\
\text { Produksi (Ha) }\end{array}$ & $\begin{array}{c}\text { Jumlah Pemilik } \\
\text { (orang) }\end{array}$ \\
\hline 1 & Banjar Kemuning & 108.3 & 52.5 & 14 \\
\hline 2 & Tambak Cemandi & 160 & 99.5 & 29 \\
\hline 3 & Kalanganyar & 11.29 & 10.5 & 2 \\
\hline \multicolumn{2}{c|}{ Total } & 351.59 & 162.5 & 45 \\
\hline
\end{tabular}

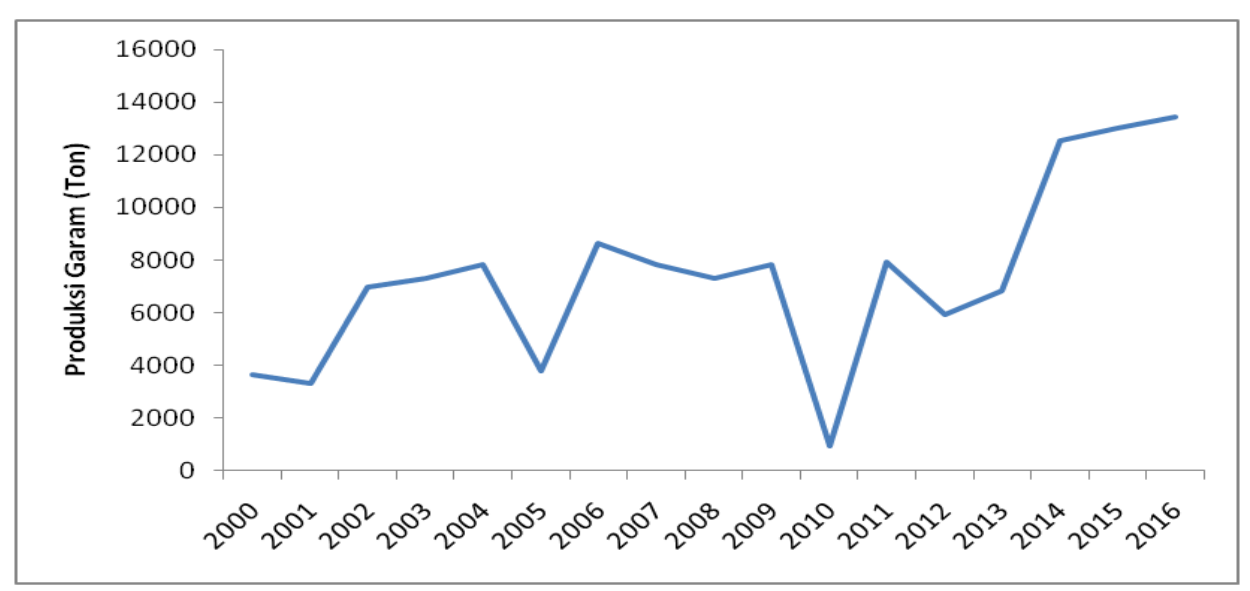

Gambar 3. Produksi Tambak Kabupaten Sidoarjo Tahun 2000-2016 
Tabel dan gambar diatas menunjukkan luas dan produksi tambak garam di Kabupaten Sidoarjo. Berdasarkan hasil pemetaan, luas tambak garam di Kabupaten Sidoarjo mencapai sekitar 351,59 Ha. Apabila dibandingkan dengan luas seluruh tambak garam di Jawa Timur yang mencapai $12.278 \mathrm{Ha}$, maka Kabupaten Sidoarjo menyumbang 2,85\% dari total luas tambak garam di Jawa Timur.

Perhitungan selanjutnya menunjukkan bahwa dari seluruh lahan tambak garam di Sidoarjo, hanya $162,5 \mathrm{Ha}(46,15 \%)$ saja yang merupakan lahan produktif. Berdasarkan sebarannya, lahan tambak garam di Kabupaten Sidoarjo terletak di Desa Banjar Kemuning, Tambak Cemandi dan Kalanganyar. Lebih lanjut, luas Iahan garam terbesar terdapat di Desa Tambak Cemandi yaitu $160 \mathrm{Ha}$ atau 45,58\% dari total luas keseluruhan.

Gambar 3 menunjukkan trend produksi garam Kabupaten Sidoarjo pada periode tahun 2000-2016. Berdasarkan data tersebut, dapat terlihat bahwa produksi garam cenderung fluktuatif. Pada tahun 2000 tercatat produksi garam 3.651 ton, meskipun mengalami sedikit penurunan pada tahun 2001, produksi garam meningkat dua kali lipat menjadi $6.976 \mathrm{Ha}$ pada tahun 2002. Produksi garam kembali meningkat pada tahun 2004 yaitu sebesar $7.819 \mathrm{Ha}$, namun pada tahun 2005 produksi garam turun drastis hingga hanya mencapai $50 \%$ dari tahun sebelumnya. Setelah mengalami penurunan tersebut, produksi garam kembali melonjak naik pada tahun 2006. Pada tahun tersebut, produksi garam meningkat lebih dari 5000 ton dibandingkan tahun 2005. Periode tahun 2006 hingga 2009 ditandai dengan stabilnya produksi garam pada kisaran $7.200-7.800$ ton, namun anjloknya produksi garam kembali terulang pada tahun 2010. Pada tahun tersebut, Kabupaten Sidoarjo mengalami produksi garam terendah dalam 15 tahun terakhir yaitu hanya 952 ton atau hanya $12,16 \%$ bila dibandingkan tahun sebelumnya. Kondisi produksi garam kembali menunjukkan perbaikan pada tahun
2011 dengan adanya peningkatan yang sangat signifikan, yaitu mencapai hampir 8.000 ton. Setelah mengalami sedikit fluktuasi pada tahun 2011 hingga 2013, produksi garam Kabupaten Sidoarjo cenderung naik secara signifikan hingga mencapai 13.430 ton pada tahun 2016 .

Sebagai salah satu usaha yang tergantung pada kondisi alam, produksi garam seperti yang terdapat di Kabupaten Sidoarjo sangat dipengaruhi oleh cuaca. Besarnya intensitas matahari, curah hujan, kecepatan angin serta laju evaporisasi adalah beberapa factor yang menentukan produksi garam. Berdasarkan analisa data dari studi-studi sebelumnya, diduga bahwa menurunnya produksi garam pada tahun 2005 dan 2010 diakibatkan oleh tingginya curah hujan dan pendeknya musim kemarau. Hal ini didukung oleh beberapa penelitian oleh Korovessis dan Lekkas (2006); Zhiling dan Guangyu (2009) yang menunjukkan adanya slope negative pada persamaam regresi antara curah hujan dan perubahan salinitas air garam pada kolam peminihan.

Lahan yang digunakan sebagai lahan produksi garam, sebaiknya dipilih lahan atau daerah yang memiliki luasan lahan yang cukup luas dengan tempat pemasukan air laut yang mudah. Letak lahan tersebut sebaiknya tidak terlalu jauh dan tidak terlalu dekat dengan laut dan rawa-rawa, serta memiliki tingkat kelembaban udara yang rendah (Dradjid dan Muakmam 2007). Lahan produksi garam yang letaknya telalu dekat dengan laut maka akan menyebabkan air laut dapat menyapu tambak garam pada saat air laut pasang. Sedangkan lahan produksi garam yang letaknya dekat dengan rawa-rawa maka lahan tersebut akan memiliki tingkat kelembaban udara yang tinggi. Hal tersebut disebabkan karena pada saat hujan Iahan yang lokasinya dekat dengan rawa-rawa maka akan tergenang air hujan kemudian dapat menyebabkan kelembaban semakin meningkat sehingga dapat mempengaruhi proses penguapan (Purbani 2006). 
Kumala dan Sugiarto (2012) menjelaskan fluktuasi produksi garam pada tahun 2009 dan 2010 dengan mengambil studi kasus di Kabupaten Sumenep. Penelitian tersebut menyebutkan bahwa kondisi iklim tahun 2009 sangat mendukung proses pembuatan garam. Pada tahun tersebut curah hujan sangat kecil saat musim produksi serta didukung oleh musim kemarau yang panjang. Dengan demikian proses produksi garam menjadi lancar karena salinitas air garam pada kolamkolam peminihan dapat meningkat secara signifikan dengan didukung oleh evaporasi yang tinggi dan curah hujan yang rendah. Berbeda dengan tahun 2010, ,salinitas air garam tidak mampu meningkat secara signifikan karena hujan sering terjadi pada saat musim produksi. Musim kemarau pada saat itu sangat singkat. Sementara itu, tahun 2011 produksi garam meningkat kembali namun masih lebih rendah dari pada produktivitas rata-rata. Proses produksi garam pada tahun tersebut mengalami keterlambatan memulai dan mengakhiri jika dibandingkan dengan musim kemarau yang benar-benar terjadi.Produktivitas garam akan menurun ketika besar curah hujan pada musim produksi besar.

\section{KESIMPULAN}

Penelitian ini berhasil menunjukkan aplikasi sederhana dari metode pemetaan menggunakan perangkat Sistem Informasi Geografis dengan data yang diperoleh dari penginderaan jauh untuk memetakan tambak garam di Kabupaten Sidoarjo. Hasilnya menunjukkan bahwa luas lahan tambak garam di Kabupaten Sidoarjo adalah 351,59 $\mathrm{Ha}$ dengan 162,5 $\mathrm{Ha}$ diantaranya adalah lahan produktif. Analisa yang dilakukan terhadap trend produksi garam di Kabupaten Sidoarjo menunjukkan hasil yang berfluktuatif pada periode tahun 2000 hingga 2016. Fluktuasi produksi ini diakibatkan oleh perubahan kondisi cuaca. Produksi garam cenderung meningkat pada saat terjadi musim kemarau yang panjang, sebaliknya saat terjadi periode musim hujan yang panjang, produksi garam mengalami penurunan yang sangat signifikan.

\section{DAFTAR PUSTAKA}

Adiraga, Y, dan Setiawan. A.H. 2014. Analisis Dampak Perubahan Curah Hujan, Luas Tambak Garam, dan Jumlah Petani Garam Terhadap Produksi Usaha Garam Rakyat di Kecamatan Juwana Kabupaten Pati (Periode 2003-2012). Skripsi. Fakultas Ekonomika Dan Bisnis Universitas Diponegoro Semarang

Aprilia. E.U., \& Ali, N.Y. 2011. Produksi Garam Merosot. Koran Tempo, 7 Januari 2011

Darmawan, A. 2012. Panduan Praktikum Sistem Informasi Geografi. Jurusan Kehutanan Fakultas Pertanian Unila. Bandar Lampung.

Kumala, A.R., \& Sugiarto, Y. 2012. Analisis Pengaruh Curah Hujan terhadap Produktivitas Garam Studi Kasus: Pegaraman I Sumenep PT. Garam (Persero). Prosiding Seminar Nasional Sains IV. Bogor. 10 November.

Korovessis N.A \& Lekkas T.D. 2006. Comparison of Solar Saltworks With Saline Coastal Wetlands. Proceedings of the $1^{\text {st }}$ of the International Conference on the Ecological Importance of Solar Saltworks (CEISSA 06); Santorini Island, Greece, 20-22 Oktober. .

Purbani, D . 2006. Buku Panduan Pembuatan Garam Bermutu. Badan Riset Kelautan dan Perikanan Pusat Riset Wilayah Laut dan Sumberdaya Nonhayati.

Purbani, D. 2011. Proses Pembentukan Kristalisasi Garam. Trisakti Geology, Vol. 84, Hal 1-17. 
Tambunan, R.B., Hariyadi \& Santoso A. 2012. Evaluasi Kesesuaian Tambak Garam Ditinjau dari Aspek Fisik di Kecamatan Juwana Kabupaten Pa. Journal of Marine Research, Vol.1, No.2, Halaman 181-187.

Wirjodirjo, B. 2004. Skenario Kebijakan Pengembangan Pergaraman Nasional Dalam Usaha Mengurangi Ketergantungan Luar Negeri: Suatu
Penghampiran Model Sistem Dinamik. Jurnal Eksekutif, Vol I(1), April 2004

Zhiling J., \& Guangyu Y. 2009. The Promotion of Salt Quality Trough Optimizing Brine Concentration A New Technique "Bidirectional Brine Concentration". Journal of Global NEST 11(1):58-63. 